\title{
Penerapan Konsep Rechtsvinding dan Rechtsschepping oleh Hakim dalam Memutus Suatu Perkara
}

\author{
Application towards the Concept of Rechtsvinding and Rechtsschepping \\ by the Judges in Deciding a Case
}

\author{
Harifin A. Tumpa \\ Badan Arbitrase Nasional Indonesia \\ Jln. Mampang Prapatan No. 2, Jakarta, 12760, Indonesia. \\ Tel./Fax:+62-217940543 E-mail: a.j.cakrawala@gmail.com
}

Submitted: Jul 22, 2015; Reviewed: Aug 9, 2015; Accepted: Aug 14, 2015

\begin{abstract}
The judge may not refuse to examine and to decide a case which has been submitted to the court despite having unclear or non-existent legal pretext. The judge are expected to be able to explore values and sense of justice that grows and embodies the community as the living law. The concept of justice here is not the outcome by the human intellectuality, but rather from his/her own spirit. A justice could not exist or be born from a mere theory, because justice is naturally born from the deepest conscience of a judge who is also a human being. A person's conscience can not come in sudden, but was born through the process, practice or habit. Either legal finding (Rechtsvinding) or the creation of law (rechtsschepping) should be used in providing justice for litigants as follows: First, in absence of the relevant rules within the existing legislation. Second, regulated by the law but insufficiently clear and contain multi-interpretations. Third, regulated by the law but no longer meet the public sense of justice (out of date). Fourth, based on a jurisprudence or an expert opinion.
\end{abstract}

Keywords: Decision; Justice; Living Law; Rechtsvinding; Rechtsschepping; The Judge

\begin{abstract}
Abstrak: Hakim tidak boleh menolak untuk memeriksa dan memutus perkara yang diajukan padanya sekalipun dengan dalih hukumnya tidak jelas atau tidak ada. Hakim dituntut untuk dapat menggali nilai-nilai dan rasa keadilan yang tumbuh dan hidup dalam masyarakat. Konsep keadilan di sini bukanlah hasil dari intelektual manusia, melainkan dari jiwanya. Suatu keadilan tidak bisa muncul atau lahir dari suatu teori, sebab keadilan itu lahir alami dari hati nurani yang paling dalam dari seorang hakim yang juga manusia. Hati nurani yang murni dari seseorang tidak dapat datang tiba-tiba, melainkan ia lahir dari suatu proses dan latihan atau kebiasaan. Penemuan hukum (rechtsvinding) ataupun penciptaan hukum (rechtsschepping) haruslah dalam koridor untuk memberikan keadilan bagi pencari keadilan. Penerapan konsep rechtsvinding ataupun rechtsschepping hanya boleh dilakukan hakim apabila: Pertama, tidak ditemukannya aturan hukum yang relevan dalam perundang-undangan yang berlaku. Kedua, diatur dalam perundang-undangan tetapi tidak jelas maknanya atau mengandung pelbagai penafsiran. Ketiga, aturan yang ada di dalam perundang-undangan tidak lagi memenuhi rasa keadilan masa kini (out of date). Keempat, didasarkan pada suatu yurisprudensi atau pendapat ahli.
\end{abstract}

Kata Kunci: Hakim; Keadilan; Living Law; Putusan; Rechtsvinding; Rechtsschepping 


\section{PENDAHULUAN}

Perundang-undangan yang dibuat oleh pembuat undang-undang dilakukan untuk mengatasi suatu masalah atau mengantisipasi suatu keadaan, sehingga undang-undang kadang-kadang tidak sempurna. Undangundang yang dibuat itu sering sudah ketinggalan zaman, tidak sesuai lagi kebutuhan masyarakat. Dalam situasi seperti ini, pembaharuan undang-undang tentu diperlukan.

Perubahan undang-undang tidak semudah yang kita pikirkan. Diperlukan penelitian lebih lanjut, kajian ilmiah serta naskah akademik, sehingga proses legislasi demikian membutuhkan waktu yang tidak singkat. Padahal di satu sisi, hakim dalam menghadapi suatu perkara, tidak dapat menolak mengadili suatu perkara dengan alasan tidak ada aturan hukum yang dapat dipakai. Hakim harus berusaha menemukan hukum baik yang tertulis maupun tidak tertulis. Apabila tidak ditemukan dalam aturan tertulis dan tidak tertulis, ia wajib menciptakan hukum (judge made law).

Peraturan perundang-udangan hanyalah merupakan sebagian dari hukum yang berlaku. Selain aturan hukum tertulis, masih ada sumber hukum (the source of law) yang lain. Di negara-negara yang menganut Civil Law System, sumber hukum selain undangundang (dalam arti luas) juga dikenal traktat, doktrin dari ahli serta Yurisprudensi. Di negara-negara yang menganut Common Law System dikenal:

1. Case Law/Judge Made Law.

2. Customery Law/Convention.

3. Writing of Jurist.

4. Practisies of lawyers (Hakim, Jaksa dan Pengacara).
Hukum merupakan sarana mengatur tata kehidupan suatu masyarakat, sehingga ia harus dinamis sejalan dinamika suatu masyarakat. Bahkan terkadang hukum itu diadakan untuk kebutuhan perkembangan masyarakat dimasa yang akan datang, seperti yang diungkapkan oleh Roscoe Pound "law as a tool of sacial engineering". Ungkapan tersebut sering diartikan "hukum sebagai sarana pembaharuan masyarakat". Walaupun diantara para pakar mengartikan kata "law" ada perbedaan, tetapi dalam prakteknya, makna dan tujuannya sama.

Bagir Manan misalnya, melihat makna kata "law" dalam law as atool of social engeneering adalah hukum yang dibuat hakim (judge made law). Dengan perkataan lain, konsep Pound dapat juga diartikan sebagai peran hakim sebagai sarana pembaharu masyarakat. Sedangkan penulis yang lain, Mochtar Kusumaatmaja dan para pemikir serupa, melihat "hukum sebagai sarana pembaharuan sosial" lebih memberi perhatian pada undang-undang atau peraturan perundang-undangan. ${ }^{1}$

Menurut penulis, perbedaan tersebut tidak menjadi soal, sebab baik "perundangundangan" maupun "putusan hakim" masing-masing adalah sumber hukum dalam membentuk norma atau kaidah hukum. Pembaharuan hukum tentu harus berasal dari sumbernya (sumber hukum), karena tidak mungkin ada perubahan atau pembeharuan hukum apabila sumbernya sendiri tidak pernah berubah atau diperbaharui oleh sumber hukum lainnya.

\footnotetext{
1 Bagir Manan. (2009). Menegakkan Hukum Suatu Pencarian, Jakarta: Asosiasi Advokat Indonesia (AAI), hlm 164.
} 
Pembaharuan atau penggantian suatu undang-undang tidak akan terjadi apabila tidak diubah melalui proses perundang-undangan yang berlaku ataukah diubah melalui sumber yang lain, misalnya yurisprudensi (putusan hakim) atau oleh doktrin ilmu hukum. ${ }^{2}$

\section{ANALISIS DAN PEMBAHASAN}

\section{Hakim Bukan Corong Undang-Undang}

Ajaran Montesquieu, bahwa hakim adalah corong dari undang-undang (spreekhuis van de wet- Belanda atau bousche de la loi- Prancis atau mouth of the law-Inggeris) merupakan konsep yang menghendaki hukum hanyalah undang-undang yang tertulis secara lengkap dan sistimatis dalam suatu Kitab Undang-Undang (kodifikasi). Tidak ada hukum selain undang-undang. Aliran ini disebut ajaran "legism”. Ajaran ini sudah lama ditinggalkan karena, undang-undang yang dibuat pada suatu masa dan kondisi tertentu belum tentu cocok diterapkan untuk sepanjang masa.

Tugas hakim Indonesia sebagai pelaksana kekuasaan kehakiman dan peradilan dirumuskan oleh Undang-Undang Dasar 1945 Pasal 24 ayat (1) yang menyatakan bahwa "Kekuasaan Kehakiman adalah kekuasaan yang merdeka untuk menyelenggarakan peradilan guna menegakkan hukum dan keadilan". Didalam tugas penyelenggaraan peradilan itulah, peranan hakim sangat menentukan guna menerapkan dan menegakkan hukum dan keadilan. Tugas hakim tidak hanya menegakkan undang-undang yang tertulis, tetapi juga hukum yang tidak tertulis

2 Harfin A. Tumpa. (2013). Pembentukan Norma Hukum Perdata melalui Yurisprudensi". Bahan Kuliah Universitas Pasundan, Bandung, hlm 1. tergantung dari kasus yang dihadapi.

Dalam hal kasus yang dihadapi sederhana yang sudah diatur dengan jelas dan terang, hakim cukup menerapkan peraturan substantif yang bersangkutan, tanpa harus melakukan penalaran yang rumit, tetapi sekedar menerapkan silogisme. Namun dalam kasus-kasus yang rumit dan menarik perhatian masyarakat, hakim harus hati-hati dalam menangani dan memutuskan perkara itu, karena mungkin saja persoalan hukumnya agak rumit untuk menuju keadilan yang menjadi tujuan dari suatu penegakan hukum.

Memang hakim kadang-kadang dihadapkan pada persoalan seolah antara hukum yang dipakai tidak sinkron dengan keadilan yang akan dicapai. Tidaklah mudah bagi seorang hakim untuk memadukan antara "hukum" dan "keadilan" dalam putusannya. Apalagi kalau kita melihat kondisi sekarang ini, masih banyak peraturan yang berasal dari peninggalan Hindia Belanda, masih banyak peraturan perundang kita yang tidak jelas karena multitafsir atau saling bertentangan satu dengan lainnya. Atau aturan-aturan undang-undang yang ada tidak sejalan tuntutan keadilan yang tumbuh di masyarakat. Hakim tidak boleh mengabaikan hukum yang ada, dan tidak boleh pula meninggalkan keadilan yang tumbuh di masyarakat.

Hukum adalah sesuatu yang nyata, baik berupa undang-undang atau hukum tertulis atau tidak tertulis lainnya, maka hukum adalah "tubuh". Di dalam tubuh itulah ada "roh keadilan", yang harus diimplementasikan hakim dalam putusannya. Dalam putusan hakim, hukum adalah landasannya putusan, dan keadilan adalah rohnya putusan. Putusan hakim harus mempunyai landasan 
hukum, baik yang tertulis maupun tidak tertulis, hukum materiil (hukum substasial) maupun hukum formal (hukum prosedural) adalah perwujudan dari azas legalitas yang dianut oleh suatu negara hukum. Roh keadilan yang harus menjiwai hukum itu adalah merupakan perwujudan dari tujuan penegakan hukum.

Suatu putusan tanpa menghirauan keadilan, sama dengan menghilangkan masa depan manusia. Bahkan bisa lebih dari itu dapat menimbulkan kekacauan yang lebih besar. Hugo de Groot, seorang filosof Belanda pernah memberi peringatan bahwa "vbi ivdicia devicivnt incipit bellvm", artinya "ketika suatu putusan tidak memberikan keadilan, maka disitulah mulainya perang."”3

\section{Bagaimana Mewujudkan Keadilan Itu?}

Inti persoalannya adalah bagimana hakim mewujudkan keadilan itu? Karena persoalan keadilan itu relatif, tergantung dari segi mana orang melihatnya, dan kepentingan apa yang mendasari penilaian itu. Clearence Darrow pernah menyatakan bahwa "Justice means different things to different people". Tidaklah mengherankan apabila terhadap suatu putusan hakim, selalu ada yang menyatakan adil dan di lain pihak menyatakan tidak adil. Para Hakim itu harus menerima sebagai suatu kenyataan. Namun kadangkadang yang cukup menyakitkan hakim adalah ketidakpuasan terhadap suatu putusan disamakan dengan ketidakadilan disertai tudingan latar belakang suap atau keberpihakan.

Harifin A. Tumpa, (2012). Menguak Roh Keadilan dalam Putusan Hakim Perdata, Jakarta: Tanjung Agung, hlm 30.
Terkait hal ini, Achmad Ali pernah menyatakan:

“.... bahwa tujuan hukum itu untuk mewuudkan keadilan semata-mata, masih jauh lebih mudah ketimbang menjawab pertanyaan apa yang dimaksud keadilan. Adil itu bagaimana dan yang tidak adil itu yang bagaimana?". ${ }^{4}$

“... saya sendiri meragukan pandangan yang menyatakan tujuan hukum adalah semata-mata keadilan. Sebab keadilan itu sendiri seuatu yang abstrak, subyektif karena keadilan bagaimanapun menyangkut nilai etika yang dianut oleh masing-masing individu". ${ }^{5}$

Dalam kenyataan, adil atau tidaknya suatu putusan, hanya dapat dinilai setelah putusan itu diucapkan oleh hakim dan telah diketahui oleh publik. Penulis sendiri yang telah berkecimpung di dunia peradilan hampir 50 tahun dan hampir 45 tahun sebagai hakim -mulai dari hakim tingkat pertama sampai puncak tertinggi di lembaga peradilanbelum menemukan resep yang manjur untuk menemukan keadilan itu, walaupun sudah banyak penulis yang menguraikan tentang konsep "keadilan". Kata keadilan adalah kata yang "highly ambigue and preguant with various meaning" (bersifat ambigu dan penuh bermacam-macam pengertian). ${ }^{6}$

Mary Harney menyatakan "There is one justice, not exelusive compartement, called civil justice, criminal justice, social justice or economic justice”. Keadilan mengandung nilai-nilai universal pada tingkat

\footnotetext{
$4 \quad$ Ahmad Ali. (2002). Menguak Tabir Hukum, Suatu Kajian Filisofis dan Sosiologis. Jakarta: Toko Gunung Agung, hlm 217.

5 Ibid.

6 J. Djohansyah, (2008). Reformasi Mahkamah Agung menuju Indepedensi Kekuasaan Kehakiman. Jakarta: Kasam Blanc, hlm 30.
} 
emosi atau perasaan setiap manusia, sekalipun tidak dapat memberikan pengertian secara jelas karena "justice is not something you can see. It is not temporal but eternal. How does man know what is justice. It is not the product of his intelect but his spirit" (keadilan bukanlah sesuatu yang dapat dilihat. Keadilan tidak bersifat sementara tetapi abadi. Bagaimana orang dapat mengetahui keadilan itu. Keadilan bukanlah hasil dari inteleltual manusia, tetapi dari jiwanya). ${ }^{7}$ Suatu keadilan tidak bisa muncul atau lahir dari suatu teori, karena keadilan itu bukan pengertian. Keadilan adalah suatu kualitas hasil dari suatu perbuatan yang dinilai adil setelah diadakan pemisahan, seleksi mana yang benar dan mana yang salah. ${ }^{8}$

Keadilan itu lahir alami dari hati nurani yang paling dalam dari seorang hakim yang juga manusia. Namun masaalahnya adalah bagaimana bisa kita meyakini kebenaran hati nurani yang murni itu? Menurut saya, hati nurani yang murni dari seseorang itu tidak dapat datang tiba-tiba, melainkan ia lahir dari suatu proses dan latihan/kebiasaan. Proses hati nurani yang murni dari seseorang, hanya dapat timbul dari :

a. Pribadi yang independen, tidak dipengaruhi oleh siapapun atau apapun. Ia tidak dapat dipengaruhi oleh atasan atau sanak saudara atau pertemanan. Ia tidak dipengaruhi oleh materi, uang atau iming-iming apapun juga. Ia adalah pribadi yang otentik.

b. Pribadi yang jujur untuk diri sendiri dan orang lain. Ia (bagi yang beraga-

$7 \quad$ Ibid., hlm 31.

8 Burhanuddin Salam. (1997). Etika Sosial, Asas Moral dalam Kehidupan Manusia. Jakarta: Rineka Cipta, hlm 117. ma) meyakini bahwa ada Yang Maha Kuasa yang melihat apa yang nyata dan tersembunyi. Ia dapat dipercaya dan sesuainya kata dengan perbuatannya.

c. Pribadi yang mempunyai karakter yang baik dan terpuji. Nilai seorang manusia, hanya ditentukan oleh sifat yang satu itu, berkelakuan yang baik (good character). ${ }^{9}$

d. Dengan sifat-sifat diatas, ia akan mampu bertindak dan berpendapat dengan berani dan bijaksana. Ia tidak takut kepada siapapun, kecuali kepada Yang Maha Kuasa (bagi yang beragama).

\section{Keadilan Harus Berlandaskan Hukum Penemuan hukum (rechtsvinding)}

Keadilan yang akan diterapkan hakim haruslah mempunyai landasan hukum. Menegakkan keadilan tanpa dasar hukum yang jelas dapat menimbulkan kesewenang-wenangan hakim. Disinilah peran hakim menentukan hukum in concrito. Dalam kasus-kasus yang sederhana, hakim cukup menerapkannya sesuai dengan teks Undang-undang yang bersangkutan, tidak perlu penalaran yang rumit, tetapi sekedar melakukan penafsiran substantif dengan menerapkan silogisme.

Dalam kasus-kasus yang rumit hakim kadang-kadang harus menggunakan segala alat bantu yang memungkinkannya untuk menemukan hukum yang dapat menunjang tegaknya keadilan yang diyakini kebenarannya. Penemuan hukum (rechtsvinding) oleh hakim semata-mata dimaksudkan untuk menegakkan keadilan. Penemuan hukum oleh hakim harus dilakukan dengan sangat

Ibid, hlm 98. 
hati- hati, karena sering dalam praktek penemuan hukum itu disalahgunakan, yaitu sekedar mencari dasar pembenaran untuk keuntungan pihak-pihak yang berperkara (karena keberpihakan).

Peristiwa hukum (fakta) yang ditemukan oleh hakim dalam memeriksa perkara, kadang-kadang tidak ditemukan kaidah hukum yang pas atas fakta itu atau kaedah hukum yang cocok dengan peristiwa hukum (fakta) itu tidak lagi sesuai dengan kondisi saat ini. Sehingga memerlukan pembaharuan (social engeneering) atau ada lebih dari satu aturan hukum yang saling bertentangan/ berbenturan mengatur fakta hukum yang bersangkutan. Dalam situasi yang demikian itu, hakim diperkenankan menggunakan alat bantu untuk menentukan hukum yang menguasai peristiwa (fakta) itu. Menurut ilmu pengetahuan, alat bantu yang dikenal adalah:

a. Metode interpretasi

Metode penafsiran substantif, yaitu hakim menerapkan suatu teks undang-undang terhadap suatu kasus konkrit, tanpa penalaran yang rumit, tetapi sekedar menerapkan silogisme.

Metode penafsiran gramatikal, yaitu hakim menafsirkan bunyi undangundang itu menurut tata bahasa yang benar dan berlaku.

Metode penafsiran sistimatis atau logis, yaitu hakim menafsirkan suatu peraturan dengan menghubungkan dengan peraturan atau pasal lain atau dengan keseluruhan sistem hukum.

Metode penafsiran historis, yaitu hakim menafsirkan suatu pasal atau peraturan dengan melihat sejarah pembentukannya, apa maksud pembuat un- dang-undang membuat peraturan yang bersangkutan.

Metode penafsiran sosiologis, yaitu menafsirkan suatu peraturan dengan menghubungkan status dan kondisi masyarakat saat ini atau kondisi yang baru. Penafsiran banyak digunakan dalam usaha hakim untuk mendorong pembaharuan dalam masyarakat.

Metode penafsiran komparatif, yaitu menafsiran suatu peraturan dengan membandingkannya dengan pelbagai sitem hukum. Penafsiran ini banyak digunakan dalam sengketa terhadap perjanjian internasional.

Metode penafsiran restriktif, yaitu menafsiran suatu peraturan dengan membatasi atau mempersempit arti suatu peraturan.

Metode penafsiran ekstentif, adalah kebalikan dari penasiran retriktif, yaitu penasiran yang melampaui batas yang diberikan oleh penafsiran gramatikal.

Metode penasiran futuristis, yaitu penasiran suatu peraturan dengan mengacu pada suatu peraturan yang belum berlaku (ius constituendum).

Metode penafsiran komprehensif. Hakim yang menggunakan metode ini, dapat mereduksi teks undang-undang atau sebalikya dapat pula menginduksi makna realitas suatu teks. Metode ini mempunyai tujuan:

- Mampu menghasilkan makna kebutuhan masyarakat.

- Bersifat kontemporer yaitu realitas dimana ia muncul.

- Bersifat realistik kehidupan dengan segala problemanya. 
b. Metode konstruksi hukum

Metode konstruksi hukum di negaranegara eropa kontinental pada umumnya tidak membedakan dengan metode interpretasi, namun di negara-negara Anglo Saxon dibedakan dengan jelas.

L.B.Curzon, seperti yang dikutip oleh Achmad Ali, mengatakan bahwa:

"Interpretasi dan konstruksi hukum mempunyai ari yang berbeda, interpretasi hanya menentukan arti kata-kata dalam suatu undang-undang, sedangkan konstruksi hukum mengandum arti pemecahan atau pengurangan makna ganda, kekaburan dan ketidak pastian dari perundang-undangan sehingga tidak bisa dipakai dalam peristiwa konkrit yang diadilinya". ${ }^{10}$

Metode konstrusi hukum mengenal adanya 3 (tiga) konsep:

Pertama, "analogi". Metode ini digunakan oleh hakim terhadap suatu kasus yang tidak tersedia peraturannya, tetapi peristiwa itu ada kemiripannya dengan peristiwa/kasus yang sudah ada aturan dalam per-undang-undangan; Kedua, “argumentum a contrario". Metode ini menggunakan penalaran bahwa jika undang-undang menetapkan hal-hal tertentu untuk suatu peristiwa tertentu, berarti peraturan itu terbatas pada peristiwa tersebut dan tidak berlaku bagi peristiwa lainnya yang berbeda; Ketiga, "rechtsvervijning atau penghalusan hukum. Konstruksi ini ada yang menyebutnya sebagai penyempitan hukum, ada pula yang menyebutnya sebagai pengkonkritan hukum. Metode ini digunakan terhadap suatu masaalah

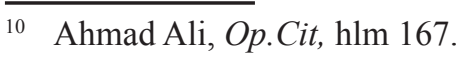

hukum yang disebut dalam suatu peraturan perundang-undangan, namun peraturan itu dipandang terlalu umum dan sangat luas pengertiannya sehingga perlu dikonkritkan atau diperhalus.

\section{Hakim menciptakan hukum (rechtsschep- ping)}

Hakim tidak boleh menolak suatu perkara yang diajukan kepadanya, dengan alasan tidak ada undang-undang atau perturan hukum yang mengatur kasus tersebut. Ketiadaan undang-undang atau eraturan hukum mewajibkan hakim untuk menciptakan peraturan agar kasus yang dianganinya bisa diselesaikan. Dengan melihat begitu besar kewenangan hakim dalam menerapkan hukum, sehingga diperlukan kehati-hatian yang tinggi dan tanggung jawab yang besar serta integritas yang tidak tercela, agar kewenangan yang besar itu tidak disalah gunakan. Mahkamah Agung sebagai pengawas tertinggi atas jalannya peradilan juga dituntut untuk mengawasi para hakim agar kekuasaan yang sangat besar itu tidak disalah gunakan.

Penemuan hukum ataupun penciptaan hukum haruslah dalam koridor untuk memberikan keadilan bagi pencari keadilan. Harus pula diingat bahwa tugas hakim hanyalah menegakkan hukum dan keadilan. Ia bukanlah pembuat Undang-undang, sehingga penggunaan lembaga rechtsvinding ataupun rechtsschepping hanya boleh dilakukan hakim apabila :

- Tidak ditemukan aturan hukumnya didalam perundang-undangan yang ada.

- Diatur dalam perundang-undangan namun tidak jelas maknanya atau 
mengandung pelbagai penafsiran.

- Aturan yang ada di dalam perundangundangan tidak lagi memenuhi rasa keadilan masa kini (out of date).

- Didasarkan pada suatu yurisprudensi atau pendapat ahli.

Hal lain yang juga perlu diingatkan adalah salah satu koridor penting bagi hakim dalam penggunaan rechsvinding dan rechrsschepping adalah apakah masaalah yang ditangani itu adalah merupakan kompetensinya? Karena kekuasaan hakim telah dibatasi kewenangannya. Kewenangan Hakim Pengadilan Agama telah ditentukan dalam Undang-Undang No. 50 Tahun 2009 tentang Peradilan Agama. Hakim Pengadilan Militer dan Pengadilan TUN juga begitu, Hakim ad hoc di Pengadilan Tipikor juga kewenangannya dibatasi. Hakim praperadilan juga kewenangannya dibatasi oleh Pasal 77 KUHAP. Mahkamah Konstitusi juga harus taat asas kepada kewenangan yang diberikan Undang-Undang Dasar atau Undang-Undang Nomor 24 Tahun 2003 tentang Mahkamah Konstitusi. Ia bukanlah pembentuk undang-undang yang dapat membuat norma baru.

\section{Penemuan Hukum Dapat Menjadi Yuris- prudensi}

Walaupun peradilan Indonesia tidak mengenal sistem preseden atau azas the binding force of presedent atau stare decises, yang berarti putusan-putusan hakim terdahulu tidak wajib diikuti oleh hakim-hakim lainnya yang menangani kasus yang hampir yang sama. Hal ini berbeda dengan sistem yang dianut oleh negara-negara Anglo Saxon, dimana hakim-hakim wajib mengikui pu- tusan-putusan hakim terdahulu yang telah memutus perkara yang serupa, karena putusan hakim adalah merupakan sumber hukum utama.

Namun demikian putusan-putusan hakim Indonesia, terutama putusan Mahkamah Agung yang mempunyai nilai "landmark decision" tidak bisa diabaikan begitu saja oleh hakim-hakim ditingkat bawah dengan dasar pemikiran: Pertama, bila perkara tersebut kemudian sampai ketingkat kasasi, maka apabila putusan berbeda dengan pendapat Mahkamah Agung, maka putusannya dapat dibatalkan; Kedua, dengan perbedaan yang tajam akan menimbulkan ketidak pastian hukum. Kepastian Hukum harus dijaga oleh Mahkamah Agung dan lembaga peradilan agar kepercayaan publik dapat terjaga.

Penemuan hukum oleh hakim, yang pada dasarnya memberi suatu pengertian konkrit atas suatu peraturan, dapat dipandang sebagai "landmark decision" yang bila kemudian diikuti oleh Hakim-hakim lainnya akan terbentuk yurisprudensi sebagai sumber hukum. Putusan-putusan hakim yang merupakan penemuan hukum, bisa membawa perubahan, penegasan atau pengkonkritan norma yang sudah ada dalam perundangundangan.

a. Penemuan hukum yang membawa
perubahan.

Dalam perkembangan zaman, kadangkadang suatu norma/aturan hukum tidak lagi memenuhi rasa keadilan yang ada di dalam masyarakat. Dalam praktik, misalnya: Pasal 1519 KUH Perdata (BW), mengatur mengenai jual-beli dengan hak membeli kembali. Dalam pasal ini ditentukan bahwa "Kekuasaan untuk membeli kembali barang yang 
telah dijual diterbitkan dari suatu janji dimana sipenjual diberikan hak untuk mengambil kembali barang yang dijualnya, dengan mengembalikan harga pembelian asal, disertai penggantian yang disebutkan dalam Pasal 1532”.

Pada tahun sekitar tahun 1980 Majelis Kasasi yang diketuai Prof. Azikin Kusuma Atmadja, berpendapat bahwa, ketentuan pasal ini bertentangan dengan hukum adat yang tumbuh pada masyarakat Indonesia, karena "jual-beli“" dengan "hak membeli" kembali se sungguhnya adalah "gadai" atau pinjam meminjam uang dengan jaminan tanah. Menurut Hukum Adat gadai, selalu menempatkan pemberi gadai yang notabene ekonomi lemah, dalam keadaan kurang dilindungi. Kita lihat misalnya Pasal 1532 KUH Perdata, betapa berat beban yang harus ditanggung penjual.

Putusan ini telah menjadi yurisprudensi, karena telah diikuti oleh hakim-hakim sesudahnya. Terakhir adalah putusan MA No.1774 K/Pdt/2005, yang dalam pertimbangannya dikatakan: Perjanjian yang terjadi antara penggugat dan tergugat adalah perjanjian dengan hak membeli kembali yang menurut yurisprudensi tetap Mahamah Agung, perjanjian seperti bertentangan dengan hukum adat. Putusan ini juga telah menyimpangi asas kebebasan berkontrak sebagaimana yang diatur dalam Pasal 1338 KUH Perdata. Hakim disini terlihat menggunakan metode penafsiran sosiologis untuk mengesampingkan ketentuan Pasal 1519 KUH Perdata (BW) tersebut.

Dalam bidang hukum pidana kita kenal sampai saat ini adalah ketentuan dalam KUHAP yang menentukan bahwa ketentuan pasal 244 KUHAP yang menyatakan: "terhadap putusan perkara pidana yang diberikan pada tingkat terakhir oleh Pengadilan lain selain Mahkamah Agung, dapat diajukan kasasi, kecuali putusan bebas".

Pada praktiknya, putusan bebas dikenal dua macam yaitu vrijspraak (bebas murni) dan ontslag van rechtsvervolging (lepas dari segala tuntutan hukum). Berdasarkan putusan Mahkamah Agung yang dilakukan dengan konsisten sampai saat ini, pengertian "bebas" dalam Pasal 244 KUHAP tersebut hanyalah putusan bebas murni (vrijspraak), sedangkan putusan lepas dari segala tuntutan hukum (ontslag van rechtsvervolging) atau biasa juga disebut "bebas terselubung" dapat diajukan kasasi oleh Penuntut Umum, apabia ia dapat membuktikan bahwa putusan itu sesungguhnya bukan putusan bebas murni.

Hakim disini menerapkan metode penasiran restrektif atau dapat juga dipandang menggunakan penghalusan hukum (rechtsvervijning).

b. Penemuan hukum yang memperluas pengertian suatu norma.

Dahulu kala dimana-mana istri bukan ahli waris. Waris menurut istilahnya "Darah", tetapi karena jasanya, karena emansipasi, sekarang ini dimana-mana isteri itu sudah menajadi waris sama dengan anak. Yurisprudensi dalam hal ini dimulai dengan putusan Mahkamah Agung 1955 dalam perkara Dr.Suratman Erwin, perkara warisan di Bandung ini yang warisannya harus dibagi 3 antara anaknya dengan ibunya (isteri) berhak atas warisan". ${ }^{11}$

11 Subekti. (1998). Perbandingan Hukum Perdata. Jakarta: Mahkamah Agung Bina Yustitia, hlm 64. 
Begitu pula yang terjadi di beberapa daerah lainnya di Indonesia, tak terkecuali di daerah Sulawesi Selatan. Dahulu kala anak perempuan tidak mempunyai hak waris (Tapanuli) atau bagian anak perempuan hanya separuh dari anak laki-laki, namun perkembangan kemudian emansipasi wanita, hak laki-laki dan perempuan sama. Hal ini diakui oleh Yurisprudensi. Dalam putusan Mahkmah Agung No.129 K/Sip/1961 tanggal 23 Oktober 1961 dinyatakan bahwa "Mahkamah Agung sebagai hukum yang hidup diseluruh Indoneia, juga ditanah Karo, bahwa anak perempuan dan anak laki-laki dari seorang peninggal warisan bersama-sama berhak atas harta warisan dalam arti bahwa anak laki-laki adalah sama dengan bagian anak perempuan. ${ }^{12}$ Putusan ini telah ikuti oleh putusan-putusan lainnya, antara lain: Putusan Nomor 415 K/Sip/ 1970 dan No.182 K/Sip/1970.

Dalam putusan ini terlihat hakim menggunakan penafsiran sosiologis, bahkan dapat dipandang sebagai upaya hakim untuk mendorong pembaharuan masyarakat (social engeneering). Penemuan hukum lain yang cukup klasik didalam dunia hukum perdata adalah perkembangan pengertian perbuatan melawan hukum (onrecht matige daad) dalam Pasal 1365 KUH Perdata (BW). Pasal ini sama bunyinya dengan Pasal 1401 BW Belanda yang menyatakan: "Tiap perbuatan melawan hukum yang membawa kerugian bagi orang lain mewajibkan orang yang karena saahnya menerbitkan kerugian itu, mengganti kerugian”.

12 Rehngena Purba. (2012). Menuju Pradigma Baru Dalam Perkembangan Hukum di Indonesia. Medan: Alumni Fakultas Hukum Universitas Sumatera Utara, hlm 346.
Pengertian melawan hukum pada mulanya (sebelum tahun 1919) hanyalah perbuatan yang bertentangan dengan undangundang yang ada. Tetapi setelah adanya putusan HR dalam kasus Lindenbaum - Cohen, pandangan HR berubah. Dalam kasus ini, baik Lindenbaum maupun Cohen adalah dua perusahaan yang bergerak dibidang percetakan, sehingga mereka timbul persaingan satu dengan lainnya.

Dengan maksud untuk menarik pelanggan-pelanggan Lindenbaun, maka perusahaan Cohen dengan pelbagai upaya, membujuk salah seorang pegawai Lindenbaun agar ia mau membuka dan memberitahu kepada Cohen, salinan dari penawaran-penawaran yang dilakukan Lindenbaum kepada Masyarakat, dan memberitahu nama-nama orang-orang yang mengajukan order kepada Lindenbaum.

Tindakan Cohen ini tercium oleh Lindenbaum. Ia kemudian menggugat Cohen di Rechtbank Amsterdam dengan dalil bahwa Cohen telah melanggar hukum (onrehtmatige daad) yang melanggar 1401 BW. Rechbank mengabulkan gugatan itu, tetapi di tingkat banding Raad van Justitie membatalkan putusan Rechtbank dengan pertimbangan bahwa Cohen tidak pernah melaggar suatu pasalpun dalam undang- undang yang berlaku. Lindenbaum mengajukan kasasi ke HR, dan ternyata HR membenarkan Lindenbaum.

Putusan tanggal 31 Januari 1919 ini menjadi monumental dan sangat terkenal dalam sejarah hukum karena merupakan tonggak sejarah dalam perkembangan yang revolusioner tentang perbuatan melawan hukum (onerechtmatige daad). Dalam putusan 
tersebut HR menyatakan bahwa yang dimaksud dengan perbuatan melawan hukum bukan hanya melanggar undang-undang yang tertulis seperti yang ditafsirkan selama ini, melainkan juga termasuk kedalam perbuatan melawan hukum adalah setiap tindakan :

a. Melanggar hak orang lain yang dijamin oleh Hukum; atau

b. Perbuatan yang bertentangan dengan kewajiban hukum pelaku, atau

c. Perbuatan yang bertentangan dengan kesusilaan, atau

d. Perbuatan yang bertentangan dengan kepatutan, keteletian dan kehati-hatian dalam kehidupan bermasyarakat, yang biasa disingkat "Patiha".

Putusan tersebut kemuadian menjadi preseden bagi hakim-hakim lainya, yang antara lain dalam kasus "Cerobong Asap" di Colmar dan Kasus Moker Heide (1937). ${ }^{13}$

Selain unsur melawan hukum yang sering menjadi perdebatan adalah adanya kerugian yang ditimbulkan perbuatan melawan hukum itu. Pada umumnya hakim berpendapat, bahwa kerugian yang ditimbulkan adanya perbuatan melawan hukum itu adalah kerugian yang telah nyata-nyata diialami seseorang atau kerugian yang terwujud. Namun pendapat ini kemudian berubah dengan adanya putusan MA No.1022 K/Pdt/2006 yang dikenal dengan kasus "Pohon Mangga. Putusan ini diangkat oleh seorang peneliti Widodo dalam disertasinya di Universitas Indonesia tahun 2011. Dalam disertasi tersebut dinyatakan bahwa:

“...Tidak kalah kualitasnya dengan putusan "Cerobong Asap Palsu" dan

13 Munir Fuady. (2005). Perbuatan Melawan Hukum, Pendekatan Kontemporer, Bandung: PT Citra Adtya Bakti, hlm 10.
"Lindenbaum-Cohen" (di Belanda), di Indonesia terdapat putusan perkara "Pohon Mangga". Kasus ini dipandang menarik karena pertama karena kasus ini sebenarnya bukan kasus yang basah, karena obyek sengketanya tidak berkaitan dengan uang, hanya menuntut agar tergugat menebang dua pohon mangga yang dikhawatirkan mengancam keselamatan jiwa dan kerugian barang. Kedua, dalam putusannya hakim melakukan terobosan hukum yang menurut peneliti bernilai "landmark decision". ${ }^{14}$

Kasus ini bermula pada tahun 1986, Penggugat (H.A.M. Thalib) membeli sebidang tanah garapan beserta rumah semi permanen. Sewaktu Penggugat menempati rumah tersebut, ada dua pohon manga yang ditanam oleh Tergugat (Kapten Pol. H Purba Tondang) masih kecil dan satu pohon sudah mulai berbuah tumbuh di tepi jalan umum yang berbatasan dengan rumah penggugat.

Masalah mulai muncul tatkala pohon mangga tersebut makin besar, yang dapat mendatangkan bahaya atau kerugian terhadap bangunan dan warga sekitarnya, jika terjadi angin kencang, sehingga pohon itu tibatiba roboh. Pohon yang makin besar, dahan dan daunnya sudah sampai diatap rumah Thalib. Begitupun akarnya sudah menjalar kepekarangan Thalib. Karena alasan itu, penggugat berusaha meminta secara kekeluargaan dengan menghubungi RT setempat agar Purba menebang pohonnya dan akan diberi ganti rugi.

Dalam musyawarah, Purba menolak permintaan Penggugat tersebut. Thalib kemudian berusaha meminta bantuan atasan

14 Widodo Dwi Putro. (2011). Tinjauan Filosofis terhadap Pradigma Positivisme Hukum. (Disertasi). Program Pascasarjana Universitas Indonesia, hlm 242. 
tergugat (Kapolda), namun usaha tersebut tidak mendapat tanggapan. Thalib kemudian membuat surat kepada walikota. Walikota setelah mempelajari surat tersebut, mengirim surat kepada Purba agar pohonnya ditebang. Namun Purba membalasnya dan menyatakan tidak bersedia menebang pohon tersebut. Setelah Pemda menerima surat, maka walikota membuat surat yang intinya, karena Purba menolak menebang pohon tersebut, maka apabila dikemudian hari terjadi kerugian orang lain atau kecelakaan terhadap jiwa orang lain adalah tanggung jawab Kapten Pol Purba Tondang.

Karena proses penyelesaian damai yang tak kunjung tercapai, akhirnya Thalib mengajukan gugatan ke Pengadilan Negeri Jayapura, dengan alasan tergugat telah melakukan perbuatan melawan hukum. Pada tingkat Pengadilan Negeri, gugatan penggugat dikabulkan, tetapi dalam tingkat banding putusan pengadilan negeri dibatalkan dengan alasan: 1) Tergugat kurang pihak, yang seharusnya Negara turut digugat; dan 2) Gugatan penggugat prematur (karena pohonnya belum tumbang).

Di tingkat kasasi, putusan Pengadilan Tinggi dibatalkan dan mengambil alih putusan Pengadilan Negeri, dengan pertimbangan bahwa kerugian tidak selalu harus diartikan adanya kerugian materil (yang sudah ada), tetapi kerugian juga dapat diartikan apabila kerugian itu mengancam hak dan kepentingan orang lain (penggugat). Perbuatan tergugat yang menolak menebang dua pohon mangga diatas tanah negara/rencana badan jalan yang dapat mengganggu dan membahayakan rumah penggugat atau perumahan yang ada disekitarnya adalah Perbuatan Mel- awan Hukum.

Logika dari putusan tersebut adalah "Bayangkan betapa tersiksanya orang terancam, seberapa lama gangguan dan rasa takut itu ia tanggung. Hukum tidak boleh sebagai "pemadam kebakaran". Mencegah lebih baik dari pada melaksanakan tindakan repressif. Jangan berfikir too legal atau legisme, tetapi yang lebih penting bagaimana hukum memberikan rasa keadilan dan kemanfaatan. Kalau kita menunggu pohon roboh (dan kemudian menimbulkan kerugian -pen) kemanfaatan hukum tidak ada. Dalam kasus ini, hakim tidak menjatuhkan ganti rugi materil,kerugian sebagaimana dimaksud tidak hrus dibayar dengan uang. Tindakan memotong pohon yang membahayakan keselamatan penggugat dan keluarganya adalah bentuk kompensasi. Putusan ini memang belum ternyata diikuti hakim-hakim lainnya, tetapi paling tidak putusan ini merupakan "landmark decision".

Demikianlah sekelumit uraian saya tentang Penemuan Hukum oleh hakim dalam mengadili suatu perkara. Di satu sisi penemuan hukum itu diperlukan oleh Hakim-Hakim progressif untuk menemukan keadilan, tetapi disisi yang lain dapat menjadi bumerang karena dapat disalah gunakan oleh hakim-hakim yang mencari "keuntungan" dengan menyalah gunakan wewenangnya.

\section{PENUTUP}

Konsep keadilan bukanlah hasil dari intelektual manusia, melainkan dari jiwanya. Suatu keadilan tidak bisa muncul atau lahir dari suatu teori, sebab keadilan itu lahir alami dari hati nurani yang paling dalam dari seorang hakim yang juga manusia. Hati nurani yang 
murni dari seseorang, tidak dapat datang tiba-tiba, melainkan ia lahir dari suatu proses dan latihan atau kebiasaan.

Penemuan hukum (rechtsvinding) ataupun penciptaan hukum (rechtsschepping) haruslah dalam koridor untuk memberikan keadilan bagi pencari keadilan. Harus pula diingat bahwa tugas hakim hanyalah menegakkan hukum dan keadilan. Ia bukanlah pembuat undang-undang, sehingga penerapan konsep rechtsvinding ataupun rechtsschepping hanya boleh dilakukan hakim apabila: Pertama, tidak ditemukan aturan hukumnya didalam perundang-undangan yang ada. Kedua, diatur dalam perundangundangan tetapi tidak jelas maknanya atau mengandung pelbagai penafsiran. Ketiga, aturan yang ada di dalam perundang-undangan tidak lagi memenuhi rasa keadilan masa kini (out of date). Keempat, didasarkan pada suatu yurisprudensi atau pendapat ahli.

\section{BIBLIOGRAFI}

Ahmad Ali. (2002). Menguak Tabir Hukum, Suatu Kajian Filisofis dan Sosiologis. Jakarta: Toko Gunung Agung.

Bagir Manan. (2009). Menegakkan Hukum suatu Pencarian. Jakarta: Assosiasi Advokat Indonesia.

Burhanuddin Salam. (1997). Etika Sosial, Asas Moral dalam Kehidupan Manusia. Jakarta: Rineka Cipta.
Harifin A. Tumpa. (2011). Reformasi Mahkamah Agung, Yogyakarta: Rangkang Education \& Pukap Indonesia. . (2012). Menguak Roh Keadilan dalam Putusan Hakim Perdata, Jakarta: Tanjung Agung. (2013). Pembentukan Norma Hukum Perdata melalui Yurisprudensi". Bahan Kuliah Universitas Pasundan, Bandung.

J. Djohansyah. (2008). Reformasi Mahkamah Agung menuju Indepedensi Kekuasaan Kehakiman. Jakarta: Kasam Blanc.

Munir Fuady. (2005). Perbuatan Melawan Hukum, Pendekatan Kontemporer, Bandung: PT Citra Adtya Bakti.

Rehgena Purba. (2012). Menuju Pradigma Baru Dalam Perkembangan Hukum di Indonesia. Medan: Alumni Fakultas Hukum Universitas Sumatera Utara.

Rahmadi Usman. (2003). Perkembangan Hukum Perdata dalam Dimensi Sejarah Politik Hukum di Indonesia. Jakarta: Pustaka Sinar Harapan.

Subekti. (1998). Perbandingan Hukum Perdata. Jakarta: Mahkamah Agung Bina Yustitia.

Subekti， R. Tjitrosudibio. (1996). Kitab Undang-undang Hukum Perdata, Burgelijk Wetboek dengan tambahan Undang-Undang Pokok Agraria dan Undang-Undang Perkawinan. Jakarta: PT Pradnya Paramita.

Widodo Dwi Putro. (2011). Tinjauan Filosofis terhadap Pradigma Positivisme Hukum. (Disertasi). Program Pascasarjana Universitas Indonesia. 